ROCZNIKI PEDAGOGICZNE

Tom 11(47), numer specjalny - 2019

DOI: http://dx.doi.org/10.18290/rped.2019.11s-32

ANNA ZARZYCKA

\title{
GŁÓWNE SPORY WOKÓŁ KARY ŚMIERCI
}

\section{WSTĘP}

Geneza kary kryminalnej jako odpłaty za wyrządzone krzywdy upatrywana jest najczęściej w instytucji zemsty krwawej, tj. spontanicznej reakcji, spowodowanej poczuciem krzywdy w wyniku naruszenia pewnego uznawanego w danej grupie dobra. Sprawców najpoważniejszych przestępstw, godzących w interesy całej społeczności rodowej, pozbawiano ochrony rodu i wykluczano ze wspólnoty. Jest to pierwowzór późniejszej instytucji wyjęcia spod prawa, z której - wraz z powstaniem państwa - wykształciła się między innymi kara śmierci (Lernell, 1977, s. 60-61).

Kara śmierci zawsze budziła wiele kontrowersji i sprzeczności w jej ocenie. Wielu uczonych i myślicieli uznawało ją za zbędną, a wręcz deprawującą dla człowieka. Aby kara taka mogła zostać orzeczona, musi zostać spełnionych kilka wymogów, bez których nie będzie można o niej mówić. Obowiązujące w Polsce prawo karne nie wypowiada się wprost na temat sensu kary. Jednakże z brzmienia przepisów k.k. dotyczących zasad wymiaru kary i przepisów k.k.w. na temat celów wykonania kary możemy wnioskować o poglądach ustawodawcy w tej kwestii. Ogólnie rzecz biorąc, ustawodawstwo karne i praktyka wykonywania prawa są przesiąknięte rozmaitymi wydaniami mieszanych teorii kary. Na poszczególnych etapach działania prawa karnego różne cele kary wysuwają się na pierwszy plan. Na etapie ustawowego zagrożenia dominuje prewencja generalna. Na etapie sądowego wymiaru kary najpełniej występuje pluralizm celów, ale odpłata (cel sprawiedliwościowy) zdaje się grać główną

Mgr Anna Zarzycka - doktorantka w Katedrze Pedagogiki Opiekuńczej, Instytut Pedagogiki, Katolicki Uniwersytet Lubelski Jana Pawła II, Al. Racławickie 14, 20-750 Lublin; e-mail: annazarzycka001@gmail.com; ORCID: 0000-0002-6915-6949 
rolę. Natomiast na etapie wykonywania kary na pierwszy plan zdecydowanie wychodzi prewencja indywidualna (Wąsek, 1999, s. 115; Pierzchała, 2008).

Z kolei „kara kryminalna jest to przewidziana przez prawo karne reakcja na czyn przestępczy, w której wyraża się dezaprobata owego czynu, a także jego sprawcy" (Marek, 1997, s. 78). Kara kryminalna jest wymierzana w imieniu państwa przez wymiar sprawiedliwości, prawomocnym wyrokiem, z poszanowaniem bezstronności stron, $\mathrm{tj}$. sprawcy i ofiary.

W Encyklopedii pedagogicznej XXI wieku J. Ultra-Milecki definiuje karę w następujący sposób: „kara fizyczna i/lub psychiczna dolegliwość, która dotyka kogoś, kto naruszył wyznaczone normy lub reguły wyznaczające określone sposoby postępowania (może być kara bogów, Boża, kościelna, służbowa, administracyjna, pedagogiczna): dolegliwość ta może mieć charakter: nieunikniony - kara naturalna lub celowy, zamierzony - kara kryminalna (Pilch, 2003, s. 127).

Zagrożenie karą jest nieodłączną cechą pojęcia przestępstwa. Przede wszystkim zagrożenie karą wyraża negatywną ocenę społeczeństwa o czynie społecznie niebezpiecznym, bezprawnym, odpowiadającym znamionom ustawowym i zawinionym przez sprawcę. Dopiero na skutek tej oceny, wyrażonej w zagrożeniu karnym, czyn poddany temu zagrożeniu w ustawie staje się przestępstwem. Z drugiej strony zagrożenie karą jest skierowaną do ewentualnego sprawcy takiego czynu zapowiedzią zrealizowania wobec niego kary, w razie popełnienia tego czynu. Innymi słowy, ,za czyn zabroniony grozi kara nie wszystkim bez wyjątku, lecz tylko osobom mającym zdolność do odpowiedzialności karnej, którą osiąga się nie z chwilą urodzenia, lecz dopiero w określonym wieku" (Świda, 1978, s. 184).

Mieczysław Ciosek wyróżnia cztery funkcje kary: odwetową, eliminacyjną, odstraszającą i poprawczą. Funkcja odwetowa jest reakcją społeczeństwa na czyny szkodliwe i destruktywne, naruszające obowiązujące normy. Funkcja eliminacyjna pozwala wykluczyć z życia społecznego te jednostki, które są w konflikcie z prawem. Funkcja odstraszająca zakłada, że ważąc ewentualne zyski i straty w przypadku popełnienia czynu przestępczego, jednostka wybierze zachowania nienaruszające prawa. Funkcja poprawcza, nazywana też wychowawczą, związana jest z założeniem, że w przypadku konieczności, człowieka można zmienić tak, by przestrzegał istniejących zasad i prawa. Powyższe funkcje kary wyrażają oczekiwanie społeczeństwa, iż spełnią pokładane w nich nadzieje. Nie gwarantują jednak skuteczności wobec wszystkich przestępców, zarówno potencjalnych, jak i rzeczywistych (Ciosek, 1995, s. 114-116). 


\section{STANOWISKA RETENCJONISTÓW}

Jedną ze stron reprezentujących swoje poglądy na temat kary śmierci są retencjoniści, którzy opowiadają się za utrzymaniem tej formy karania, godząc się z pewnymi ograniczeniami jej stosowania. $Z$ drugiej strony abolicjoniści sprzeciwiają się zachowaniu kary śmierci w ustawodawstwie karnym.

Pojmowanie kary jako odpłaty opiera się na koncepcjach Immanuela Kanta i G.W.F. Hegla, którzy karę postrzegają jako konieczną reakcję na przestępstwo. Kant jest twórcą teorii odwetu sprawiedliwego, co oznacza, że każdy człowiek podlega regule zobowiązującej go do spełniania dobrych uczynków, które umotywowane są poczuciem obowiązku. Regułą tą jest norma kategoryczna: „Postępuj tylko według takiej maksymy, dzięki której możesz zarazem chcieć, żeby stała się prawem powszechnym” (Szyszkowska, 1994, s. 121). Teorii Kanta przyświeca przy tym założenie, że człowiek jest celem samym w sobie, a sprawiedliwość według niego polega na odpłacie złem za zło, co oznacza, iż kara jest bezpośrednią konsekwencją zła moralnego. Kant przyjmuje, iż każde przestępstwo powinno spotkać się z odpowiedzią, przy czym jedynym rozsądnym sposobem na wyrównanie jest kara (Świda, 1978, s. 260). Jednocześnie koncepcja ta zakłada, że kara powinna być równa popełnionemu przestępstwu, dlatego reakcją na zabójstwo może być tylko i wyłącznie kara śmierci. Jednakże Kant przyjmował od tej zasady dwa wyjątki, a mianowicie gdy spowodowano śmierć nieślubnego dziecka oraz zabójstwo w pojedynku.

Dla Hegla z kolei kara jest koniecznością dialektyczną, co oznacza, że przestępstwo stanowi zaprzeczenie prawa. Kara zaś jest zaprzeczeniem przestępstwa, a odrzucenie prawa przez przestępcę jest niejako negacją ustawodawstwa karnego, któremu on sam podlega. Sprawiedliwość kary według Hegla polega na tym, iż ,_... [ jest ona zarazem wolą samą w sobie przestępcy, jest istnieniem jego wolności, jego prawa. Jest ona prawem samego przestępcy, to znaczy założona jest w jego istniejącej woli, w jego działaniu" (Lernell, 1977, s. 165). Hegel uważa, że zastosowana kara powinna być proporcjonalna do popełnionego czynu, dopuszcza jednak możliwość stosowania kar zastępczych, wyłączając z tego zabójstwo, ponieważ żaden inny sposób ukarania przestępcy nie będzie dostatecznie rekompensował pozbawienia życia innego człowieka (Stawrowski, 1994, s. 68).

Kolejnym zwolennikiem kary śmierci był Cesare Lombrosso, który dostrzegał możliwość skutecznego prewencyjnego oddziaływania kary w eliminacji czynników kryminogennych. Lombroso uważał, że uzasadnieniem kary może być jedynie unieszkodliwienie sprawcy poprzez jego fizyczną eliminację (Lernell, 1977, s. 136). 
Karę śmierci aprobowali również uczniowie Lombrosso. Jednym z nich był Rafaelle Gorofalo, który postrzegał karę śmierci jako środek eliminacji niepoprawnych przestępców. Również Franz von Liszt nie sprzeciwiał się karze śmierci, chociaż uważał on, że kara powinna być sprawiedliwa, lecz jednocześnie jej zadaniem jest powstrzymanie danego osobnika od popełniania dalszych przestępstw. Twierdził, że „nie czyn, lecz jego sprawca podlega ukaraniu" (Marek, 1997, s. 30). Dlatego w odniesieniu do przestępców niepoprawnych, do których Liszt zaliczał przestępców z nawyknienia, zawodowych, zatwardziałych recydywistów, jedynym skutecznym środkiem karnym byłoby ich unieszkodliwienie bądź długotrwała lub całkowita eliminacja (Lernell, 1977, s. 145).

Według retencjonistów cechą konstytutywną człowieczeństwa jest nie tyle wymiar biologiczny, co „zdolność odróżniania wartości od antywartości oraz intencja czynienia dobra" (Musiał, 1998, s. 13). Zwolennicy kary śmierci powołują się również na ograniczenia obowiązywania normy „nie zabijaj”. Nakaz ten, ich zdaniem, nie może być rozumiany w sposób bezwzględny i całkowity. Istnieją bowiem takie sytuacje losowe, w których jego zastosowanie zostaje niejako zawieszone. Te sytuacje to przede wszystkim obrona konieczna przed zamachem na życie oraz wojna sprawiedliwa. Zabicie człowieka w tych okolicznościach jest uznane przez ustawodawstwo karne za dopuszczalne i usprawiedliwione.

Retencjoniści uważają, iż przestępca, decydując się na pogwałcenie prawa do życia swojej ofiary, jednocześnie kwestionuje własne prawo do życia i w pewnym sensie je zawiesza. Naruszając normy chroniące życie, jednocześnie sam pozbawia się ich ochrony (Filek, 1989, s. 222).

Represjoniści twierdzą również, że w przypadku najcięższych przestępstw, a zwłaszcza zabójstw dokonanych ze szczególnym okrucieństwem, kara śmierci to jedyny środek karny odpowiadający społecznemu poczuciu sprawiedliwości. „Pogwałcone w akcie morderstwa życie ofiary trwa nadal w porządku moralnym i wywiera sobie właściwe skutki. Oznacza to, że choć uległo zniszczeniu fizyczne życie jednostki, to nie uległa i ulec nie mogła równoczesnej zagładzie zakorzeniona w świecie obiektywnych wartości jego moralna wartościowość łącznie z zawartymi w niej moralnymi roszczeniami" (Ślipko, 1988, s. 15).

W przeciwieństwie do teorii retrybutywnych, teorie prewencyjne nie postrzegają kary jako celu samego w sobie. Myśl o prewencyjnym oddziaływaniu kary pojawiła się już w starożytności. Zwolennikiem tej teorii był Platon, który uważał, że nikt nie karze przestępcy za to, że on coś zrobił, chyba że w akcie zemsty, ale za to, aby w przyszłości ten sam sprawca nie popełnił kolejnej zbrodni, która negatywnie wpłynęłaby na społeczeństwo (Grześkowiak, 1985, 
s. 33). Także Seneka twierdził, że nikt rozsądny nie karze dlatego, że popełniono przestępstwo, lecz by przestępstw nie popełniano (Świda, 1978, s. 261).

Jedno z założeń tej teorii przyjmuje, że ludzi skłonnych do naruszania prawa można od takich zachowań odstraszyć groźbą kary (Brandt, 1996, s. 831). Dlatego karanie nie może być celem samym w sobie, ale powinno zmierzać do osiągnięcia korzyści społecznych. Karanie jako takie powinno być uznane za zło, którego należy unikać, o ile nie przyniesie korzyści interesowi społecznemu. Jeżeli zaś kara ma być w ogóle orzeczona, musi być na tyle surowa, by przestępca nie odniósł korzyści z przestępstwa. Sensem kary nie jest więc odpłata, lecz skuteczność w zapobieganiu popełniania kolejnych przestępstw przez danego sprawcę lub przez innych członków społeczeństwa.

Istnieje też pogląd, jakoby morderca przez swój czyn przestawał być człowiekiem w sensie moralnym, co powoduje wyłączenie wobec niego zasady „nie zabijaj”. Jest to idea pochodząca jeszcze od św. Tomasza z Akwinu, który twierdził, że człowiek poprzez grzech zatraca swoją godność i degraduje się do poziomu zwierząt (Ślipko, 1988, s. 98-102). Takiego zdania jest także B. Wolniewicz, dla którego „człekokształtność nie stanowi kryterium człowieczeństwa”, a właśnie „człowieczeństwo, jako kategoria aksjologiczna, a nie człowiek - czy życie ludzkie jako kategoria biologiczna, jest wartością absolutną”, natomiast „są czyny, które swą immanentną ohydą przekraczają granicę człowieczeństwa" (Wolniewicz, 1995, s. 160).

\section{RACJE ABOLICJONISTÓW}

Wśród twórców teorii prewencyjnych są zarówno zwolennicy kary śmierci, jak i jej przeciwnicy. Najbardziej znanym abolicjonistą jest Cesare Beccaria. W wydanej w 1764 r. pracy O przestepstwach $i$ karach opowiedział się on za zasadą ekonomii, co oznacza, że według niego „do osiągnięcia kary wystarcza, by dolegliwość, jaką ona za sobą pociąga, przewyższała korzyści osiągane przez popełnienie przestępstwa, a ta przewaga zła powinna obejmować i nieuchronność kary, i utratę dobra, które uzyskano by wskutek popełnienia przestępstwa" (Beccaria, 1959, s. 139). Zdaniem Beccarii prawo, które jest okrutne, w istocie sprzyja bezkarności. Według Beccarii „,...] celem kary nie jest torturowanie i męczenie wrażliwej istoty ludzkiej, ani też uczynienie nieistniejącym przestępstwa, które już zostało popełnione. Cel kary sprowadza się do tego, aby przeszkodzić winnemu w wyrządzeniu nowych szkód współobywatelom oraz aby powstrzymać innych od wyrządzania szkód tego rodzaju" (Beccaria, 1959, s. 88). W swoim dziele Beccaria opowiedział się również przeciwko karze 
śmierci i uznał, że „kara śmierci nie może być pożyteczna, gdyż daje ludziom przykład okrucieństwa”. Stosowanie kary śmierci Beccaria dopuszczał tylko w dwóch przypadkach: ,jeśli przestępca nawet po pozbawieniu go wolności ma [...] jeszcze takie stosunki i wpływy, że grozi to bezpieczeństwu narodu, zaś jego istnienie może wywołać przewrót niebezpieczny dla panującego systemu rządów”, bądź „śmierć byłaby rzeczywistym i jedynym środkiem do powstrzymania innych od popełniania przestępstw" (Beccaria, 1959, s. 147).

Przeciwko karze śmierci opowiadali się również A. Feuerbach i J. Bentham, którzy odrzucali pojmowanie kary jako odwetu czy odpłaty. To właśnie Bentham uznał, że kara jest złem samym w sobie, ponieważ wiąże się z nią cierpienie i zastosowanie przymusu, dlatego może być wymierzana tylko wtedy, gdy umożliwi uniknięcie większego zła niż to, które sama niesie. Prewencyjne oddziaływanie kary wymaga, aby formą upodabniała się ona do popełnionego przestępstwa. Odebranie życia sprawcy czynu przestępnego pozbawia go wprawdzie możliwości popełnienia w przyszłości nowych przestępstw, a więc odbiera mu możliwość czynienia zła, ale również odbiera mu możliwość czynienia dobra (Lernell, 1977, s. 124).

Przeciwko karze śmierci przemawia także fakt, że kara śmierci jest nieekonomiczna, gdzie postulowana przez Benthama zasada ekonomii kary przewiduje, że kara nie powinna wyrządzać większego zła niż to, jakie zawierał w sobie czyn przestępczy (Lernell, 1977, s. 123). Zdaniem Benthama, kara będzie nieekonomiczna zarówno wtedy, gdy nie jest aprobowana przez społeczeństwo, jak i wtedy, gdy stanowi odpowiedź na przestępczość jako zjawisko występujące w skali masowej. Należy zdawać sobie sprawę również z faktu, iż kara śmierci jest nieodwracalna, a w związku z tym niebezpieczna ze względu na możliwość pomyłki sądowej.

Zasadniczym argumentem podnoszonym przez abolicjonistów jest niezbywalność prawa do życia przysługującego każdemu człowiekowi. Jednostka nie może zostać przez nikogo pozbawiona tego prawa, nie może więc ono stać się przedmiotem zamachu zwłaszcza ze strony państwa, będącego gwarantem praw.

Kara śmierci, zdaniem jej przeciwników, pozbawia skazanego prawa do godnej śmierci. Niektórzy uważają, że w ten sposób kara śmierci jednocześnie pozbawia człowieka godności życia. Podstawą rozważań abolicjonistów pozostaje właśnie afirmacja życia i uznanie jego świętości w odniesieniu do każdego człowieka.

Przeciwnicy kary śmierci odrzucają uzasadnienie tej formy kary jako zapobieganie recydywie oraz kwestionują argumentację, że przestępca swoim czynem sam ściąga na siebie karę śmierci, co oznacza, że stawia się poza zakresem prawa do życia (Filek, 1989, s. 230). Twierdzą także, że nie można 
uzasadnić stosowania kary śmierci ani przez odwołanie się do jakościowego, ani do ilościowego aspektu sprawiedliwości. Skoro najsurowsza kara powinna grozić za najcięższe przestępstwa, konieczne byłoby wtedy określenie rangi poszczególnych wykroczeń. Abolicjoniści uważają, że kara ta nie daje się stopniować, ponieważ żadne przestępstwo nie może być określane jako najbardziej szkodliwe i stanowiące największe zagrożenie dla społeczeństwa w oderwaniu od okoliczności konkretnego czynu, ponieważ zawsze możemy się spotkać z przypadkiem zbrodni o wiele bardziej drastycznej. Podnoszą oni również, że nawet jeśli zostaje ona orzeczona i wykonana bez żadnych proceduralnych uchybień, to przysparza skazanemu więcej cierpień niż doświadczyła ofiara. Oskarżony odczuwa najpierw niepewność, czy zostanie skazany, czy nie, a następnie żyje w oczekiwaniu na wykonanie kary albo zastosowanie wobec niego prawa łaski. Według abolicjonistów, kara śmierci nie jest sprawiedliwa, jeżeli przyjmiemy, że sprawiedliwość wymaga równego traktowania sprawców takich samych czynów. Poszczególne kategorie sprawców nie są nią bowiem zagrożone w takim samym stopniu (Jasiński, 1979, s. 38).

\section{WSPÓŁCZESNE PODEJŚCIA WOBEC KARY ŚMIERCI}

Pytanie o zasadność kary śmierci jest dzisiaj stawiane ze szczególną stanowczością. Współcześnie rozwijają się procesy praktycznych realizacji postulatów abolicjonistycznych w społeczeństwie. Organizacje międzynarodowe o znacznych wpływach, między innymi Amnesty International, podejmują inicjatywy prowadzące do zniesienia kary śmierci, co owocuje zmianami w licznych kodeksach karnych, które zastępują karę śmierci łagodniejszą sankcją w postaci dożywotniego pozbawienia wolności. Prezentowanie kary śmierci jako nieprzydatnej w stosunku do osób skazanych za najcięższe przestępstwa jest stałą tendencją abolicjonizmu.

Abolicjonizm, rozumiany jako kierunek w polityce kryminalnej, zmierzający do likwidacji istniejących instytucji prawnokarnych, po osiągnięciu sukcesu w zakresie zniesienia kary śmierci zwraca się ostatnio przeciwko instytucjom penitencjarnym, w szczególności karze pozbawienia wolności. Towarzyszy temu dekryminalizacja czynów dotychczas uznanych za przestępne oraz dążność do łagodzenia kar, zwłaszcza pozbawienia wolności (Kmiecik, Skrętowicz, 2002, s. 57).

Kolejnym współczesnym postulatem odnoszącym się do kary śmierci jest zasada humanitaryzmu, która powinna być bezwzględnie stosowana w wykonywaniu wyroku na skazanym. Z perspektywy lat można zauważyć, iż jeszcze 
do niedawna kara śmierci była wykonywana w sposób okrutny i nieludzki. Cytując W. Świdę: ,[...] kara śmierci obraża uczucia humanitarne człowieka. Wyrazem tego jest chociażby odraza, jaką odczuwamy do kata lub do narzędzi wykonania kary śmierci”" (Świda, 1989, s. 269).

Obecnie daje się zauważyć tendencję do bezbolesnego i szybkiego wykonywania kary śmierci, która nie pozwalałaby skazanemu odczuwać dodatkowego cierpienia. Współcześnie na płaszczyźnie utylitarystycznej pojawia się między abolicjonistami i retencjonistami spór o skuteczność kary śmierci w spełnianiu jej funkcji prewencyjnej, zarówno generalnej, jak i indywidualnej. Już Beccaria zakwestionował skuteczność kary śmierci w tym zakresie, twierdząc, że kara niewoli jest znacznie bardziej odstraszająca poprzez jej długotrwałość. Również twórca utylitaryzmu Bentham twierdził, za Beccarią, że zło zawarte w karze śmierci nie jest rekompensowane efektem prewencyjnym tej kary. Prewencyjny efekt kary śmierci jest zjawiskiem, które należy do świata faktów, a nie do świata wartości, można je więc zweryfikować empirycznie. Takie próby podejmowane były poprzez badania statystyczne i psychologiczne. Wyniki badań statystycznych, prowadzonych przez Mittermaiera i Sellina w latach sześćdziesiątych XX w., jak podaje A. Grześkowiak, nie wykazują, iż zniesienie bądź przywrócenie kary śmierci ma wpływ na zwiększenie lub zmniejszenie liczby przestępstw nią zagrożonych. Potwierdzają ten wniosek badania przeprowadzone dla ONZ w 1988 roku i zaktualizowane w roku 2002, w wyniku których stwierdzono, że ,[...] nie byłoby rozważne zaakceptowanie hipotezy, iż kara śmierci odstrasza morderców od popełniania zbrodni w znacząco większym stopniu niż groźba zastosowania przypuszczalnie lżejszej kary dożywocia" (Hood, 2002, s. 230).

\section{ZAKOŃCZENIE}

Stosunek do kary śmierci jest bardzo zróżnicowany. Nie ma jednej przeważającej grupy osób, która opowiadałaby się za lub przeciw jej wykonaniu. Kara śmierci to z pewnością problem, który w obecnym stanie możliwości badawczych nauk społecznych trudno uznać za rozstrzygnięty. Możemy więc powiedzieć, że w gruncie rzeczy argumenty ścisłe i rzeczowe tutaj zawodzą, a spór jest co do swojej istoty zderzeniem dwóch poziomów wrażliwości.

W tradycyjnych teoriach kary, do których nawiązują oba nurty, można wyróżnić dwa ich rodzaje: teorie retrybutywne oraz prewencyjne. Teorie retrybutywne przyjmują, iż kara powinna być aktem zapłaty złem za zło. Teorie prewencyjne uzasadniają karę jej społecznym oddziaływaniem. Według 
zwolenników drugiej teorii celem kary jest prewencja generalna i indywidualna, co oznacza zapobieganie w przyszłości popełnianiu przestępstw zarówno przez innych ludzi, jak i przez osobę, która to prawo naruszyła. Kara jest złem, jednak można ją zaakceptować, jeżeli skutki, jakie wywołuje w społeczeństwie, będą pozytywne.

\section{BIBLIOGRAFIA}

Beccaria, C. (1959). O przestepstwach i karach. Warszawa: Wydawnictwo Prawnicze.

Brandt, R.B. (1996). Etyka. Zagadnienia etyki normatywnej i metaetyki. Warszawa: Wydawnictwo Prószyński i S-ka.

Cioser, M. (1995). Człowiek w warunkach izolacji więziennej. Gdańsk: Wydawnictwo Archidiecezji Gdańskiej.

FileK, J. (1989). Etyka wobec problemu kary śmierci. Studia Filozoficzne, 10, 222-230.

GrześKowiak, A. (1985). Chrześcijańska wizja kary Giuseppe Bettiola. Tygodnik Powszechny, $42,33$.

Hood, R. (2002). The Death Penalty: A World-Wide Perspective. Oxford: Clarendon Press.

JASIŃSKI, J. (1979). Kara śmierci w aspekcie prawnym i moralnym. Więź, 10, 38.

Kmiecik, R., Skrętowicz, E. (2002). Proces karny. Część ogólna. Lublin: Wydawnictwo UMCS.

Lernell, L. (1977). Podstawowe zagadnienia penologii. Warszawa: Wydawnictwo Prawnicze.

Marek, A. (1997). Prawo karne. Zagadnienia teorii i praktyki. Warszawa: Wydawnictwo C.H. Beck.

Musiat, Z. (1998). Triumf człowieczeństwa. Rzeczpospolita, 50, 13.

Pierzchala, K. (2008). Kara śmierci w aspekcie prawnym i etyczno-moralnym. W: K. PierzCHAŁA, Cz. CeKIERA (red.), Zwalczanie patologii społecznych w systemie penitencjarnym Polski i USA. Toruń: Wydawnictwo Adam Marszałek.

PILch, T. (red.) (2003). Encyklopedia pedagogiczna XXI wieku (s. 127). Warszawa: Wydawnictwo Akademickie „Żak”.

Stawrowski, Z. (1994). Państwo i prawo w filozofii Hegla. Kraków: Papieska Akademia Teologiczna.

Szyszkowska, M. (1994). Zarys filozofii. Białystok: Wydawnictwo Temida2.

ŚLıPKo, T. (1988). Granice życia. Dylematy współczesnej bioetyki. Warszawa: Akademia Teologii Katolickiej.

ŚwidA, W. (1978). Prawo karne. Warszawa: Państwowe Wydawnictwo Naukowe.

Wąsek, A. (1999). Kodeks karny. Komentarz (t. 3). Gdańsk: Wydawnictwo Arche.

Wolniewicz, B. (1995). Filozoficzne aspekty kary głównej. Edukacja Filozoficzna, 20, 160. 


\section{GŁÓWNE SPORY WOKÓŁ KARY ŚMIERCI}

\section{Streszczenie}

Dyskusja tocząca się na temat kary śmierci jest oparta głównie na dwóch sprzecznych ze sobą stanowiskach. Pierwsze z nich - retencjonizm - to przekonanie co do słuszności wykonywania kary śmierci oraz godzenie się z pewnymi ograniczeniami jej stosowania. Drugim zaś jest abolicjonizm, który sprzeciwia się zachowaniu kary śmierci w ustawodawstwie karnym. Oba stanowiska opierają się na rzetelnych w przekonaniu każdej z nich opiniach oraz postulują co do słuszności swojej racji. W artykule znajduje się również krótka charakterystyka najważniejszych teorii na temat kary śmierci: teorii retrybutywnej oraz prewencyjnej, jak również poruszona zostaje kwestia współczesnego podejścia co do słuszności kary śmierci.

Słowa kluczowe: kara śmierci; przestępstwo; abolicjonizm; retencjonizm.

\section{THE MAIN DISPUTES REGARDING THE DEATH PENALTY}

\section{Summary}

The discussion on the death penalty is mainly based on two conflicting positions. The first of them - retentionism - is the belief in the rightness of executing the death penalty and accepting certain restrictions of its use. The second is abolitionism, which opposes the death penalty in criminal legislation. Both items are based on reliable opinions and postulate the rightness of their opinions. The article also contains a brief description of the most important theories on the subject of the death penalty: retrive and preventive theories, and finally the question of a modern approach to the legitimacy of the death penalty.

Key words: death penalty; crime; abolitionism; retentionism. 